\title{
PENGARUH SUHU DAN LAMA PENYIMPANAN SEDIAAN KRIM ANTI JERAWAT MENGANDUNG ANTIBIOTIK YANG DIRACIK DI APOTEK TERHADAP AKTIVITAS ANTIBAKTERI STAPHYLOCOCCUS AUREUS
}

\author{
Nizar. M,;Sarmadi; Pitaloka RF \\ Jurusan Farmasi Politeknik Kesehatan Kementerian Kesehatan Palembang \\ Email: drssarmadi@yahoo.co.id
}

Diterima : 5 Desember 2018 Direvisi : 14 Desember 2018 Disetujui : 15 Desember 2018

\begin{abstract}
Abstrak
Latar Belakang : Jerawat merupakan penyakit kulit yang umum terjadi, peradangan dapat dipicu oleh bakteri seperti Propionibacterium acnes, Staphylococcus epidermidis dan Staphylococcus aureus. Sediaan antibiotik topikal seperti neomycin, tetrasiklin, klindamisin, dan kloramfenikol cukup berguna untuk kebanyakan pasien dengan kondisi jerawat ringan hingga parah. Antibiotik topikal dapat berupa salep dan krim yang dapat mengalami perubahan karena dipengaruhi oleh suhu sehingga penyimpanannya harus diperhatikan.Metode : Jenis penelitian ini adalah penelitian eksperimental karena ada perlakuan terhadap sediaan krim antijerawat racikan yang dipengaruhi suhu dan lama penyimpanan terhadap aktivitas antibakteri dengan cara mengukur diameter zona hambat aktivitas antibakteri. Hasil:Berdasarkan hasil pengukuran diameter zona hambat pada sediaan krim antijerawat racikan yang mengandung antibiotik pada penyimpanan hari ke-28 sediaan mengalami penurunan kecuali pada krim A yang mengandung antibiotik klindamisin mengalami kenaikan.Kesimpulan : Adanya pengaruh suhu dan lama penyimpanan sediaan krim antijerawat racikan yang mengandung antibiotik terhadap daya hambat bakteri Staphylococcus aureusdengan adanya penurunan daya hambat sediaan diakhir penyimpanan.
\end{abstract}

\begin{abstract}
Background : Acne is a common skin disease, inflammation can be triggered by bacteria like Propionibacterium acnes, Staphylococcus epidermidis, and Staphylococcus aureus.Topical antibiotic preparations such as neomycin, tetracycline, clindamycin, and cloramphenicol are quite useful for most patients with mild to severe acne conditions. Topical antibiotics can be in the form of ointments and creams that can experience changes because they are affected by temperature so that storage must be considered.Method :This type of research is an experimental research because there is a treatment of preparations for anti-acne creams which are influenced by temperature and storage time for antibacterial activity by measuring the diameter of the inhibitory zone of antibacterial activity.Results: Based on the measurement of inhibitory zone diameter on antifungal cream preparations containing antibiotics in storage 28 days the dosage decreased except in cream A which contained antibiotic clindamycin increased. Conclusion: The effect of temperature and storage duration of anti-acne cream preparations containing antibiotics on the inhibitory power of Staphylococcus aureus bacteria with a decrease in dosage inhibition at the end of storage.
\end{abstract}

\section{PENDAHULUAN}

Sediaan topical merupakan salah satu bentuk obat yang sering dipakai dalam terapi dermatologi. Sediaan ini merupakan sediaan yang penggunaannya pada kulit dengan tujuan menghasilkan efek lokal
(Suhariyanto, 2011). Biasanya sediaan topical dapat berupa krim, salepdan gel yang digunakan dalam mengatasiberbagai masalah kulit seperti jerawat, panu, dan bisul. Jerawat merupakan penyakit kulit yang umum terjadi pada remaja berusia16- 
19 tahun, bahkan dapat berlanjut hinggausia 30 tahun. Peradangan dapat dipicu oleh bakteri seperti Propionibacterium acnes, Staphylococcus epidermidis danStaphylococcus aureus (Fissy, Sari, danPratiwi, 2014).

Jerawat yang terinfeksidan tidak segera mendapatkan perawatan dapat merusak struktur kulit. Kondisi jerawat yang parah dapat menimbulkan perasaan depresi dan kurang percaya diri, sehingga penderita jerawat cenderung mengunjungi dokter kulit untuk mendapatkan perawatan medis. Biasanya dokter akan memberikan salah satu antibiotik dalam resep. Sediaan antibiotik topikal seperti neomycin, tetrasiklin, klindamisin, dan kloramfenikol cukup berguna untuk kebanyakan pasien dengan kondisi jerawat ringan hingga parah. Namun, obat-obat ini dapat menimbulkan iritasi kulit atau reaksi sensitifitas pada kulit orang-orang tertentu.

Antibiotik topical dapat berupa salep dan krim yang dapat mengalami perubahan karena dipengaruhi oleh suhu sehinggapenyimpanannya harus diperhatikan. Mengkonsumsi antibiotik yang telah kadaluarsa akibat lama penyimpanan dapat menimbulkan resistensi, membunuh bakteri yang justru diperlukan tubuh, dan bisaterjadi gangguan sistem biokimia dalamtubuh (PriyambododalamAlmiralti, 2017). Penyimpanan yang tidak tepatdapat merusakobat. Mayoritas obatsebaiknya disimpan dalam suhu ruang, namuna da sebagai an obat yang harusdisimpan dalam lemariesuntuk menjaga obat tetap berkhasiat. Olehkarenaitu, obat perlu disimpan di tempat tertutup dankering, sertaaman (BPOM, 2015).

Tujuan dari penelitian ini adalah untuk mengetahui apakah terjadi perubahan diameter zona hambat antibakteri berbagai sediaan krim antijerawat yang diracik di apotek oleh pengaruh suhu dan lama penyimpanan selama 0 hari, 7 hari, 14 hari, 21 hari, dan 28 hari terhadap Staphylococcus aureus.

\section{METODE}

\section{Alat dan Bahan}

Peralatan yang digunakan dalam penelitian ini meliputi cawan petri, jarum ose, kertas cakram, kapas lidi steril, vial, dry heat oven, dan lain-lain. Dan krim antijerawat racikan mengandung antibiotik (sampel).

\section{Persiapan Sampel}

Sampel yang telah ditebus di apotek dan sudah dilakukan penyimpanan. Krim ditimbang sebanyak $1 \mathrm{~g}$. Kemudian masing-masing sampel dimasukkan ke dalam vial yang sudah disterilkan dan sudah ditandai.

\section{Pembuatan Media Mueller Hinton Agar}

1) Bahan-bahan media Mueller Hinton Agar (MHA) yang terdiri dari beef infusion $300 \mathrm{~g}$, bacio amino acid (kasein hidrolisat) 17,5 g, starch 1,5 $\mathrm{g}$ dan bacio agar $17 \mathrm{~g}$ dilarutkan dalam 1 liter aquadest.

2) Lalu ukur pH sampai 7,4.

3) Kemudian disterilkan dalam autoclave selama 15 menit pada suhu $121^{\circ} \mathrm{C}$.

4) Masukkan ke dalam cawan petri steril dengan ketebalan 3-4 mm.

5) Kemudian sterilkan kembali dalam autoclave.

\section{Pembuatan Suspensi Staphylococcus aureus}

Ambil media $\pm 150 \mathrm{ml}$ dari media Mueller Hinton Agar (MHA) yang telah dibuat dan dipanaskan pada suhu $37-40^{\circ} \mathrm{C}$, kemudian ditambahkan biakan murni bakteri sebanyak 3-5 koloni ke dalam media.

\section{Pengukuran Diameter Zona Hambat}

1) Media Mueller Hinton Agar (MHA) dituangkan ke dalam cawan petri masing-masing $10 \mathrm{ml}$ dan biarkan hingga memadat sebagai lapisan dasar.

2) Kemudian ambil suspensi bakteri Staphylococcus aureus, torehkan 
pada permukaan media Mueller Hinton Agar (MHA) secara merata dan biarkan mengering.

3) Masing-masing kertas cakram dicelupkan ke dalam masing-masing sediaan krim antibiotik topikal.

4) Masing-masing cakram dimasukkan ke media yang ada bakterinya,

5) Kemudian diinkubasi selama 24 jam pada suhu $37^{\circ} \mathrm{C}$.

6) Setelah diinkubasi lakukan pengamatan dan pengukuran terhadap zona hambat dengan menggunakan jangka sorong.

\section{HASIL DAN PEMBAHASAN}

HASIL

Setelahdilakukan pengujian daya hambat bakteri terhadap ketiga sampel yang dipengaruhi suhu dan lama penyimpanan didapatkan penurunan daya hambat dari ketiga sampel sediaan krim racikan antijerawat yang mengandung antibiotik

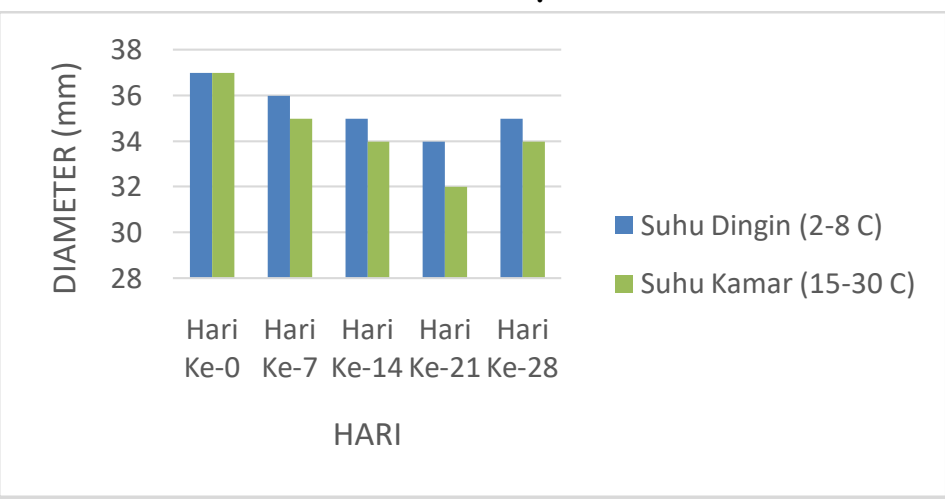

Gambar 1. Hasil Diameter Zona Hambat Krim A (Mengandung Klindamisin)

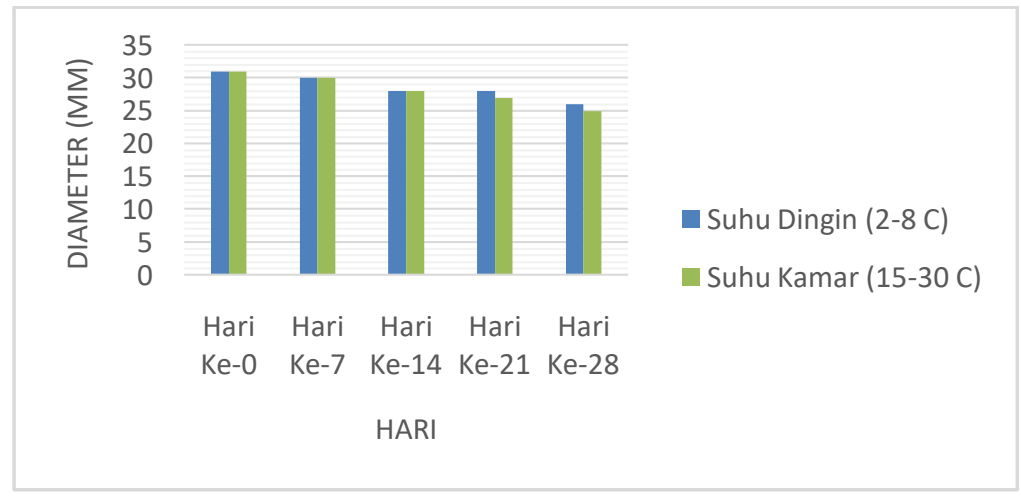

Gambar 2. Hasil Diameter Zona Hambat Krim B (Mengandung Kloramfenikol Krim)

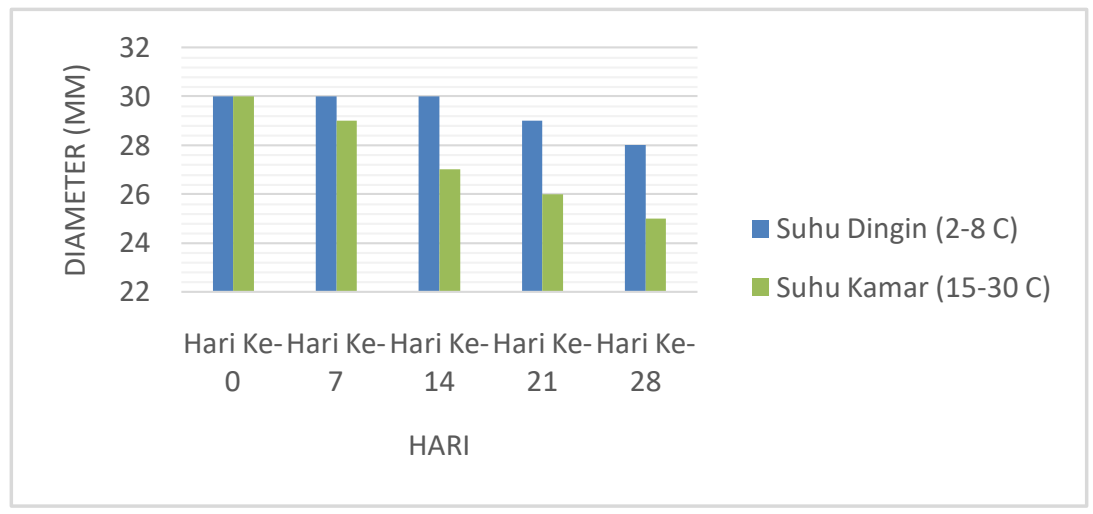




\section{PEMBAHASAN}

Penelitian ini menggunakan sampel sediaan krim antijerawat racikan yang ditebus di satu apotek Palembang. Kemudian sampel ditandai dengan label krim A, krim B, krim C. Data yang diperoleh dari sediaan adalah komposisi. Setelah dilakukan penelitian tentang uji aktivitas sediaan antibiotik topikal kulit terhadap Staphylococcus aureus yang dipengaruhi suhu dan lama penyimpanan di Balai Besar Laboratorium Kesehatan Palembang menunjukkan hasil, bahwa ketiga sediaan tersebut mempunyai daya hambat terhadap bakteri Staphylococcus aureusdan menunjukkan penurunan daya hambat karena ada pengaruh suhu dan lama penyimpanan.

Diameter zona hambat dapat dipengaruhi oleh banyak faktor antara lain, kepadatan atau viskositas dari media biakan, kecepatan difusi suatu zat, konsentrasi zat pada cakram, sensitivitas jamur terhadap zat, dan interaksi zat dengan media (Harmita dan Radji, 2008). Analisis data menggunakan SPSS Uji Statistik Independent Sampel t-Test data terlebih dahulu di uji normalitasnya, didapatkan nilai $\mathrm{p}<0,05$ itu berarti Ho ditolak atau data terdistribusi normal. Lalu seperti tabel 3 didapatkan sig > 0,05. Hal tersebut menunjukkan bahwa tidak terdapat perbedaan yang signifikan daya hambat antara suhu dingin dan suhu kamar.

\section{KESIMPULAN}

Tidak terdapat perbedaan yang signifikan bermakna aktivitas antibakteri antara suhu dingin dan suhu kamar dari ketiga sampel krim racikan.

\section{DAFTAR PUSTAKA}

Almiralti F., 2017. "PengaruhSuhudan Lama Penyimpanan Sediaan Antibiotik Topikal Kulit Setelah Segel Dibuka Terhadap Daya Hambat Bakteri Staphylococcus aureus". Politeknik Kesehatan Kementrian Kesehatan. Palembang.

Anshori M., dan Martono D., 2009. Biologi. Departemen Pendidikan Nasional. Jakarta.

Atlas R.M., Snyder J.W., 2014. Handbook of Clinical and Public Health Microbiology. Taylor\& Francis Gruop LLS (https://books.google.co.id,Diaksesta nggal 3 Februari 2018)

Aulton, M.E., Collet., Diana, M. (1990). Pharmaceutical Practice.United States of America: Churchill Livingstone Inc. Hal. 115.

Badan POM, 2015. Petunjuk Pelaksanaan Cara Distribusi Obat Yang Baik. Badan POM RI. Jakarta.

Badan POM, 2015. Pusat Informasi Obat Nasional. Badan POM RI. Jakarta. (pionas.pom.go.id, Diakses tanggal 2 Februari 2018)

Basuki, K.S. 2003. Tampil Cantik Dengan Perawatan Sendiri. Gramedia Pustaka Utama. Jakarta.

Bonner M, Benson P, James W. 2008. Topical Antibiotics. Fitzpatrick's Dermatology in general medicine, 7th ed. New York: McGraw-Hill.

Davis WW, Stout TR. Disc plate method of microbiological antibiotic assay: II. novel procedure. (Dalam Penelitian Almiralti, 2017).

Departemen Kesehatan, 1979. Farmakope Indonesia Edisi III. Departemen 
Kesehatan Republik Indonesia. Jakarta.

Departemen Kesehatan, 1995. Farmakope Indonesia Edisi IV. Departemen Kesehatan Republik Indonesia. Jakarta.

Fissy O. N., Sari R., Pratiwi L., 2014. "Efektivitas Gel Anti Jerawat Ekstrak Etanol Rimpang Jahe Merah (Zingiber officinale Rosc. Var. Rubrum) terhadap Propionibacterium acnes dan Staphylococcus epidermidis". Fakultas Kedokteran. Universitas Tanjungpura. Pontianak,hal: 2.

Gavin, J. J., 1956, Microbiology Process Report: Analytical MicrobiologiII. The Diffusion Methods, Appl. Microbial.

(DalamPenelitianAlmiralti 2017).

Harmita, dan Radji, M., 2008, Buku Ajar Analisis Hayati, Edisi 3, pp. 125-9, Penerbit Buku Kedokteran EGC, Jakarta

Hartanti, A. S., 2012. Dasar - Dasar Mikrobiologi Kesehatan. Nuha Medika. Yogyakarta,hal: 157.

Jawetz, E., Melnick, J.L. and Adelberg, E.A., 2005, Mikrobiologi Kedokteran Edisi 22., EGC Penerbit Buku Kedokteran, Jakarta.

Kusmiyati\&Agustini, N. W. S., 2007, Uji Aktivitas Anti bakteri dari Mikroalga Porphyridiumcruentum, Biodiversitas, 8, 1412-03.

Maharani, A., 2015. Penyakit Kulit. Pustaka Baru Press. Yogyakarta,hal: 1-16.

Mashuda, A., 2011, Pedoman Cara Pelayanan Kefarmasian yang Baik (CPFB), Kementerian Kesehatan RI, Jakarta. Tersedia online melalui www.scribd.com. Diakses tanggal 29 Januari 2018.

Pelczar,M.J.\& Chan,E.C.S., 2008. Dasar Dasar Mikrobiologi. UI Pres, Jakarta.

Pratiwi, S.T., 2008. Mikrobiologi Farmasi. Erlangga. Jakarta.

Smith A. J, M. S. Jackson, and J. Bagg., 2001. The ecology of Staphylococcusspecies in the oral cavity. J. Med. Microbiol,Vol. 50. The Pathological Society of Great Britain and Ireland.

Tjekyan, R.M.S, 2008. Kejadian dan Faktor Risiko Akne Vulgaris. Dalam : Media Medika Indonesia Volume 43 (halaman 37:43). Fakultas Kedokteran Universitas Diponegoro Semarang dan IDI Jawa Tengah, Indonesia.

Yuindartanto, A. (2009). Acne vulgaris. Fakultas Kedokteran Universitas Indonesia. Diunduh dari http:/yumizone.w ordpress.com/2009/01/07/acne/ (Diakses tanggal 28 Januari 2018). 